\title{
The Mediating Role of Social Media in Tourism: An eWOM Approach
}

\author{
Anish Kumar KAKIRALA ${ }^{1}$, Devinder Pal SINGH ${ }^{2}$
}

Received: August 01, 2020 Revised: September 28, 2020 Accepted: October 05, 2020

\begin{abstract}
This research article investigates the way eWOM in social media influences the formation of destination image through development of trust and satisfaction for the potential tourist. The research involved administering an 18-point questionnaire taking online reviews, tourist involvement, and eWOM, destination image components of trust and satisfaction as variables. Data was collected from 554 individuals forming a cross-section of social media users and analyzed using multi-variate techniques (Reliability, CFA, and SEM). Results indicate a positive and significant relationship between all except online review and destination trust and satisfaction. Indirect and direct effects indicate that eWOM fully mediates the relationship between destination satisfaction and involvement and partially mediates the relationship between destination trust and involvement. In the case of online reviews, eWOM acts as a full mediator between destination trust and destination satisfaction for the future traveler using social media. The study proposes that components of image vary depending upon the degree of involvement, volume online reviews and eWOM generated also termed as 'virality' and these in turn influence the intention to revisit or recommend a destination. The study highlights its utility for National Tourist Organizations (NTOs) and online travel intermediaries to enhance destination marketing efforts.
\end{abstract}

Keywords: Social Media, Tourism, eWOM, Destination Image

JEL Classification Code: C39, D81, M10, M31, Z32

\section{Introduction}

Social media is defined as a web-based application that allows people or organizations to create, share and exchange ideas, content, information and data to various other groups or individuals present on the network (Mangold \& Faulds, 2009). Social media introduces substantial changes in communication between organizations, businesses, communities and individuals (Pino et al., 2018). This sort of communication is dialogic, many sources to many receivers,

${ }^{1}$ First Author and Corresponding Author. Research Scholar, Punjabi University Regional Centre for Information Technology \& Management, Punjab, India [Postal Address: \#1397, Pushpac Housing Complex, Sector-49B, Chandigarh, 160047, India] Email: anish.kakirala@gmail.com

2Professor, Punjabi University Regional Centre for Information Technology \& Management, Mohali, Punjab, India.

Email: sidhudps@gmail.com

(c) Copyright: The Author(s)

This is an Open Access article distributed under the terms of the Creative Commons Attribution Non-Commercial License (https://creativecommons.org/licenses/by-nc/4.0/) which permits unrestricted non-commercial use, distribution, and reproduction in any medium, provided the original work is properly cited. as against the traditional media which is monologic or a single source to many receivers (Kaplan, 2012). The key aspect that marketers and consumers are adopting social media as a means of communication is the function of 'virality' or amplification of one's views through sharing of text and visual media to get a larger audience (Kaplan \& Haenlein, 2010).

Social media is playing a key role in destination marketing (Lang-Faria \& Elliot, 2012; Oz, 2015; Seven, 2013; Di Pietro et al., 2012) and a larger role in formation of destination image (Shen et al., 2015; McCartney et al., 2008). Buhalis and Law (2008) have observed that the growth in social media has played a synergistic role in the growth of tourism around the world. Social media has radically changed the way tourists are searching, planning and experiencing their holidays (Kavoura \& Stavrianeas, 2015). From the customer side, it has helped the end-user to search, plan and customize their holiday packages in a way that was not possible through traditional information methods (Fotis et al., 2011). From the service providers' side, it has helped in catering to a globalized market by developing, managing and distributing offerings worldwide (Kiralova \& Pavliceka, 2015). The 'new tourist' feels more empowered in using social media 
for seeking exceptional value for time and money (Ip et al., 2011). More and more tourists are using the social media to research and create holidays rather than going through the packaged tours method (Sigala, 2012)

Further, it is stated that tourist organizations are increasingly relying on social media as a mode of communication to effectively market and attract customers (Hays et al., 2013). The authors conclude that tourism industry is increasingly influenced by this high degree of interaction also termed as involvement between customer to customer or eWOM (Hennig-Thurau et al., 2004). This eWOM is being seen as essential in formation of destination image and also of immense value to travel intermediaries and National Tourist Organizations (NTOs) (Murphy et al., 2007). Extant literature focuses on the functional, psychological and social antecedents of tourist decision-making using social media (Parra-López et al., 2011) but scant research on eWOM and its mediating role in building destination image. This brings us to the definition of this research article.

\section{Literature Review}

\subsection{Tourist Involvement under Influence of Social Media}

Tourist products are experiential in nature and for a successful visit, potential tourists turn towards a plethora of resources available including social media. Tourists take the help of both internal and external sources for their information search purposes (Gursoy \& McCleary, 2004). To further improve the information search behavior model, Lehto et al. (2005) devised a model that integrates knowledge representation, cognitive processing and customer involvement. The study delineated involvement into two categories namely - content of search and degree of search . It also identified prior destination experience, content of search, degree of search, web-use experience as antecedents of customer's online information involvement in tourist information search.Involvement also plays a mediating role between the social media user and the formation of a positive destination image (RodriguezMolina et al., 2015).

Cai et al. (2003) have proposed a conceptual framework that takes into consideration the information search and involvement as primary influencers of tourist purchase decisions. The study delves into the psychological, social and behavioral approach towards involvement which is further categorised into high, medium and low depending on the volume of information search.

In another quantitative study by Sotiriadis and van $\mathrm{Zyl}$ (2013) on Twitter usage for generating tourist related eWOM, an attempt was made to validate the factors responsible for tourism consumer behaviour. Reliability of source, frequency of communication, expertise and knowledge of source and lastly degree of involvement were considered as the primary antecedents of eWOM. An inter-factor analysis revealed that source reliability and degree of involvement have the highest correlation with eWOM in the case of tourist products and services.

\subsection{Social Media and Role of Trust and Satisfaction in Destination Image}

Destination image is gaining ground as a major research topic in tourist decision making with a majority of research being done in the past two decades (Beerli \& Martín, 2004). Destination image is linked to concepts of tourism marketing like, tourist satisfaction, and destination choice and behavioral characteristics like loyalty, self-congruency and trust (Beerli et al., 2007). In a study conducted by Baloglu and McCleary (1999) in United States, a path-goal model was used to understand the causal relationship of tourist characteristics - social, psychological and perceptual, cognitive and affective evaluation of destination image. The direct and indirect influencing variables were taken into count to ascertain that the both perceptual/cognitive components have a strong influence in building a positive destination image. In another study conducted in Spain, the destination image is linked to independent variables like satisfaction, market heterogeneity and loyalty (Castro et al., 2007). The analysis resulted in an illustration of destination image and future behavior of tourist mediated by service quality and satisfaction.

Murphy et al. (2007) tried to link four key constructs in destination image namely - tourist self-congruity, destination personality, intention to visit and tourist needs. The findings indicated a strong link between tourist self-image and the destination branding. Many studies in the sphere of destination image focused upon the intention to revisit the destination. A latent two-factor growth model was used to find the relation between novelty, satisfaction, destination image. This data, collected from French, English and German travelers, revealed that novelty and low satisfaction hampered the desire to revisit whereas positive destination image enhanced the revisit intention (Assaker et al., 2011).

Chen and Phou (2013) have viewed the symbiotic relationship between destination image and destination loyalty through the prism of human emotions of satisfaction, attachment and trust. This research conducted on 428 visitors of Angkor temple, Cambodia used Bagozzi's (1992) attribution theory that involves cognitive knowledge, affective outcomes and behavioral outcomes.

Chi and Qu (2008) have used an integrated approach to validate the relationship between destination image, destination loyalty and tourist satisfaction. The findings suggested a direct effect of destination image on satisfaction and an indirect effect with overall satisfaction and destination loyalty. 


\subsection{Role of Online Reviews}

Social media empowers the users to create, exchange, collaborate information and make it public through online reviews and blogs (Dellarocas, 2003). This user-generated content which is topical and inhibition-less in nature is attracting the travel intermediaries and tourism boards due to its inherent value in customer insights (Puri, 2007). A research on TripAdvisor usage by hotels conducted by O'Connor (2010) on data collected from 100 hotels reveals that online reviews are the best source to gauge satisfaction or dissatisfaction amongst the customers. Hotel reviews form the basis of providing better experiences.

Lee et al. (2008) have researched the effects of negative online reviews on the choice of consumer products. Using the Elaboration Likelihood model, this study focussed on the role of negative online reviews in influencing the product purchase. The study highlighted that a high involvement of the user elicits conformity to the negative comments of the reviewers of notwithstanding the quality of the review and less involvement has the opposing effect. This study disproves the earlier notion that online reviews have no effect on the purchase intention of the users. Similar study by Sotiriadis and van Zyl (2013) delved into the influence of eWOM and online reviews on the usage of Tourism products and services. A conceptual model involving antecedents of tourist was tested using source reliability, frequency of communication, degree of involvement and source expertise. The study conducted on Twitter users from South Africa and Western Europe brought forth that if the sender has a high degree expertise and involvement in social group then the likelihood of purchase of travel products increases appreciably.

\subsection{E-Word of Mouth}

Electronic Word-of-mouth or eWOM has gained prominence in social media advertising. A study conducted on the content generated by customer reviews, highlighted that positive reviews led to a ten percent increase in the hotel's online booking (Ye et al., 2011). The eWord-ofMouth communication is central to the social media such that the power of expression lies with the content generator passes on to the members of his/her group which in turn gets transmitted to other members giving a sense of virality to the communication. The eWOMs criticality lies in the fact that dissatisfied customers tend to use Word-of-mouth behavior more than satisfied customers (Anderson, 1998).

Hennig-Thurau et al. (2004) conducted their research on eWOM by using opinion platforms and have looked into the primary motivations of users to articulate themselves over the internet. This study using regression analysis on a sample of 2000 customers took into count the motivations of eWOM behaviour from non-electronic media (Engel, Blackwell,
\& Miniard, 1993). This study confirmed that the primary motivations of indulgence in eWOM are concern for others, enhancement of self-worth and lastly economic incentives.

Litvin et al. (2008) have looked at eWOM as the primary source of information in the tourism industry. This study is of immense importance as tourism is termed as experiential product and an evaluation prior to purchase is inconceivable. The research focusses on the role of eWOM as a mediator between source and the listener. It took the prime motivations based on consumption experiences and used consumerinvolvement, surprises, brand familiarity, memory as mediating variables to deliver outcome in the the form of product acceptance, customer loyalty and final purchase decision.

In the context of tourism, social media eWOM is based upon referral behavior in the form of transfer of information from one sub-group to other relying on the social ties existing (Brown \& Reingen, 1987). The wide usage of eWOM in tourism sector is its ability to reduce uncertainty in the minds of the users and mitigate risk (Bickart \& Schindler, 2001). In the context of desitnation choice, Jalilvand and Samiei (2012) have used the Theory of Planned Behavior (Ajzen, 1991) on a sample of 296 tourists visiting Isfahan in Iran as a holiday destination .The research validated the influence of eWOM on the attitude towards destination, perceived behavioral control and subjective norms to make Isfahan the preferred choice of vacation.

\section{Research Methodology}

\subsection{Hypothesis Formulation}

The prime objective of the study is to decode how eWOM, generated in a social media community, mediates the relationship between involvement and online reviews with destination image characterized by destination trust and destination satisfaction. The questions to be answered are in what way would eWOM help in building a positive or negative image of the destination in the social media user's mind? In what way would the traveler online reviews and involvement in content creation influence the destination image? Social media is the largest growing communication medium and the user-generated content influences the tourist in all stages of the planning process- the pre-visit, visit and post-visit. The Research framework is depicted in Figure 1:

Research hypothesis proposed based on Figure 1 are:

Hola: Customer involvement has a significant and positive relationship with destination satisfaction using social media for tourism.

$H_{0}$ lb: Customer involvement has a significant and positive relationship with destination trust using social media in tourism. 


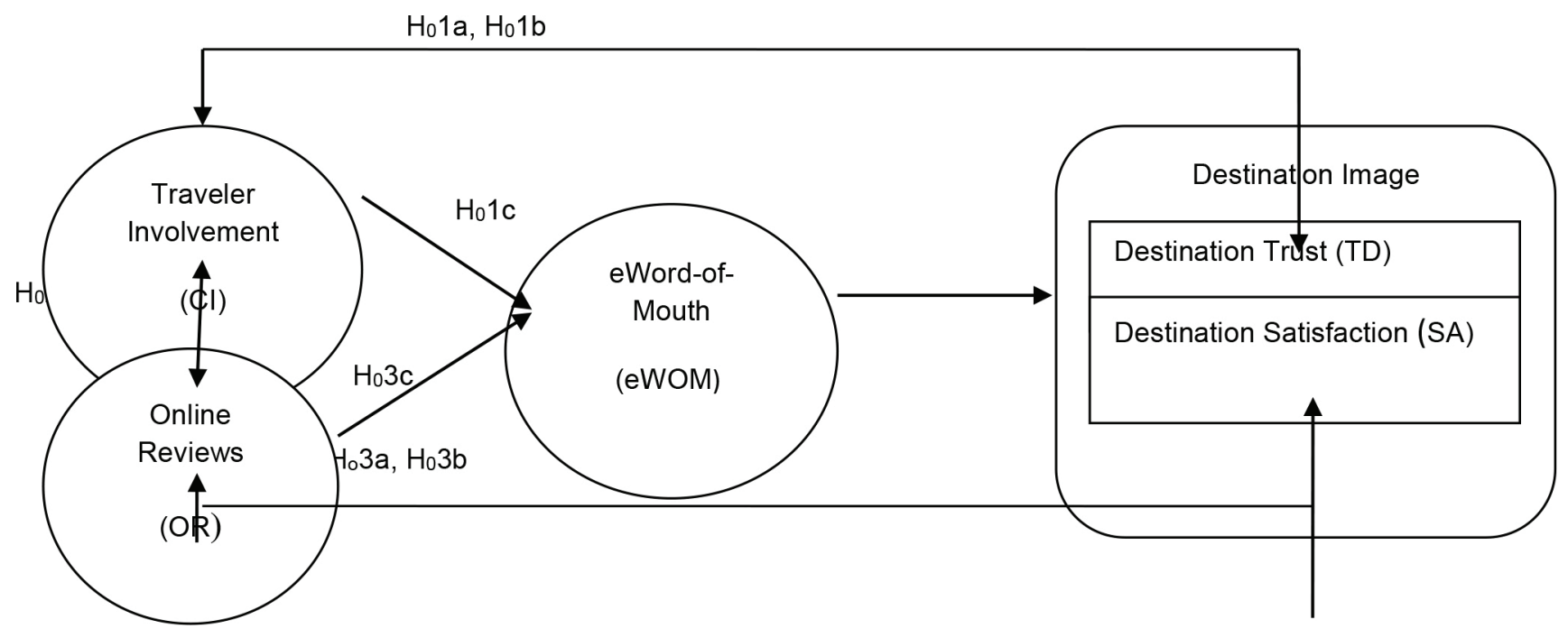

Figure 1: Schematic diagram of the research proposal

$H_{0} \mathbf{l c}$ : Customer involvement has a significant and positive relationship with eWOM in social media use for tourism.

$\mathrm{H}_{0} 2 \mathrm{a}$ : There exists a significant and positive relationship between eWOM and destination trust in social media for tourism.

$\boldsymbol{H}_{0} 2 \boldsymbol{b}$ : There exists a significant and positive relationship between eWOM and destination satisfaction in social media for tourism.

$\boldsymbol{H}_{0} 3 \mathrm{a}$ : There exists a significant and positive relationship between online reviews and destination trust using social media for tourism.

$\boldsymbol{H}_{0} 3 \boldsymbol{b}$ : There exists a significant and positive relationship between online reviews and destination satisfaction using social media for tourism.

$\boldsymbol{H}_{0} 3 \mathrm{c}$ : Online reviews have a significant and positive relationship with eWOM in social media use for tourism.

The research model assumes that the variables have an indirect and direct effect on both destination image components of trust and satisfaction and the role of eWOM as a mediator is to be established.

\subsection{Questionnaire Formulation}

Due to non-availability of standardized scale for destination image, eWOM the constructs were adopted from different studies. The constructs of involvement were drawn from study conducted by Park and Lee (2008), online review were from Bronner and de Hoog (2011), the study by Jeong and Jang (2011) for eWOM, for destination satisfaction Castro et al. ( 2007) and lastly for trust we refer to Chen and Tsai (2007). The questionnaire consists of two-parts - the research constructs form part 1 and demographics like age, income, education, gender, occupation form part 2. Table 1 illustrates the demographic profile of the respondents.

\subsection{Data Collection}

An 18-point questionnaire using 5-point Likert scale was developed from existing literature and was administered to individuals using social media. The total of 620 questionnaires were distributed and 580 were returned. After rejecting the incomplete questionnaires, we obtained a workable sample of 554 responses which gave us an acceptance rate of $89 \%$. The sample demographics are shown in Table 1 with males forming $50.4 \%(\mathrm{n}=279)$ and females $49.6 \%(\mathrm{n}=275)$ between the age group of 18 to 49 . In our sample it is observed that a large part of the respondents, approximately $55.2 \%$, belonged to the age group of 20-30 and constituted the largest users of social media (Hadddouche \& Salomone, 2018).

\subsection{Reliability Analysis}

The first step in conducting our study is to conduct analysis for data reliability and validity -both convergent and divergent. Table 2 illustrates factor loadings, construct reliability and average variance extracted (AVE). The level of internal consistency can be termed as high with Cronbach's alpha varying from 0.653 to 0.884 which is well above the threshold of 0.6 (Hair et al., 1998). All the factor loading are above the average threshold of 0.5 indicating a high convergent validity amongst the constructs (Hair et al., 1998). Except for destination image the rest of the constructs had reliability close to 0.8 and indicating an acceptable measure. 
Table 1: Demographic characteristics of the sample

\begin{tabular}{|c|c|c|c|}
\hline Category & & Frequency & Percentage \\
\hline \multirow[t]{2}{*}{ Gender } & Male & 279 & 50.4 \\
\hline & Female & 275 & 49.6 \\
\hline \multirow{3}{*}{$\begin{array}{l}\text { Marital } \\
\text { Status }\end{array}$} & Married & 215 & 38.8 \\
\hline & Single & 317 & 57.2 \\
\hline & Divorced & 22 & 4 \\
\hline \multirow[t]{4}{*}{ Age } & Below 20 & 125 & 22.6 \\
\hline & $20-30$ & 306 & 55.2 \\
\hline & $30-40$ & 86 & 15.5 \\
\hline & $40-50$ & 37 & 6.7 \\
\hline \multirow[t]{5}{*}{ Education } & Matriculation & 137 & 24.7 \\
\hline & Graduate & 291 & 52.5 \\
\hline & $\begin{array}{l}\text { Post- } \\
\text { graduate }\end{array}$ & 46 & 8.3 \\
\hline & Professional & 77 & 13.9 \\
\hline & any other & 3 & 0.5 \\
\hline \multirow[t]{8}{*}{ Employment } & $\begin{array}{l}\text { Self- } \\
\text { employed }\end{array}$ & 118 & 21.3 \\
\hline & Manager & 70 & 12.6 \\
\hline & Salesman & 70 & 12.6 \\
\hline & Academician & 80 & 14.4 \\
\hline & Clerical & 19 & 3.4 \\
\hline & Student & 162 & 29.2 \\
\hline & Defence & 28 & 5.1 \\
\hline & Unemployed & 7 & 1.3 \\
\hline \multirow[t]{6}{*}{ Income } & Below 100k & 145 & 26.2 \\
\hline & 100k-250k & 77 & 13.9 \\
\hline & $250 k-500 k$ & 104 & 18.8 \\
\hline & $500 k-750 k$ & 103 & 18.6 \\
\hline & $750 \mathrm{k}-1000 \mathrm{k}$ & 106 & 19.1 \\
\hline & above $1000 \mathrm{k}$ & 19 & 3.4 \\
\hline Total & & 554 & 100 \\
\hline
\end{tabular}

Additionally, since all the values of average variance extracted were above 0.5 giving further evidence of convergent validity (Hair et al.,1998). Further, the square root of average variance extracted is greater than correlations of the constructs indicating divergent validity existing in the constructs (Campbell \& Fiske, 1959).

\section{Results}

In the first stage of the two-step process, a confirmatory factor analysis was performed on sample using the 18 constructs related to the proposed model. This two-step process is proposed by Anderson and Gerbing (1988) in which first a confirmatory factor analysis (CFA) is performed to give reliability, validity and goodness-of-fit measure for the model under study and followed by structural equation modelling (SEM) using the maximum likelihood model to give us meaningful relationships between the variables.

The confirmatory analysis for the model $\left(\chi^{2}=2.945\right.$, $\mathrm{dF}=128, \mathrm{RMR}=0.931$ and $\mathrm{AGFI}=0.908$ at $\mathrm{p}=0.001)$ indicate a Good fit for all the parameters (Hu \& Bentler, 1999). Although the Goodness-of-fit (GFI) value of 0.931 was below the cut-off criteria of 0.95 , the value of Adjusted Goodness-of-Fit (AGFI) at 0.908 which is above 0.90 as per the norms laid by Bentler, (1990) indicating an acceptable fit for the proposed model. The Root Mean Square Error of Approximation (RMSEA) value of 0.058 is below 0.08 indicating a good-fit (Hu \& Bentler, 1999).

The confirmatory analysis is further validated by Normed Fit Index (NFI) at 0.93 which is less than threshold value 0.95 indicating an acceptable fit. The model gives a Relative Fit Index (RFI) value of 0.916 which is lesser than the cut-off criteria of 0.95 indicating an acceptable fit. The Incremental Fit Index (IFI) at 0.953 is greater than 0.95 indicating a Good fit and lastly the Tucker-Lewis Index (TLI) gives a value of 0.943 which is above threshold of 0.90 and further indicate a good model fit (Hu \& Bentler, 1999).

The next step as proposed by Anderson and Gerbing (1988) is to carry out the structural equation modeling using IBM AMOS v24. The final maximum likelihood model is illustrated by Figure 2 to show the relationships between the predictor variables and the dependent variables, in this case destination trust and destination satisfaction.

The above proposed model outlines the regression weights and the co-variances existing between the constructs and the variables under study (Fornell \& Larcker, 1981). By adding the co-variances between online reviews and involvement and destination image and destination trust, there is not much change in the proposed model. To summarize the findings of the above model we use the Table 3 and Table 4 which gives us a snapshot of regression estimates and the direct and indirect effects existing between the predictor and independent variable at level of significance 0.01 . 
Table 2: Reliability Analysis

\begin{tabular}{|c|c|c|c|c|c|}
\hline Variable & Item & Constructs & $\begin{array}{l}\text { Factor } \\
\text { Loading }\end{array}$ & Reliability & AVE \\
\hline \multirow{5}{*}{$\begin{array}{l}\text { Involvement } \\
\text { (Cronbach's } \propto= \\
0.65) \quad(\text { Park \& } \\
\text { Lee, 2008) }\end{array}$} & $\mathrm{Cl} 1$ & $\begin{array}{l}\text { I like seeing posts in social media about various } \\
\text { destinations }\end{array}$ & 0.903 & 0.848 & 0.533 \\
\hline & $\mathrm{Cl} 2$ & $\begin{array}{l}\text { I certainly like words like fabulous, enjoyable being } \\
\text { added to posts about destination in social media. }\end{array}$ & 0.659 & & \\
\hline & $\mathrm{Cl} 3$ & $\begin{array}{l}\text { I don't pay much attention to posts that recommend } \\
\text { a destination unless they are backed by information }\end{array}$ & 0.653 & & \\
\hline & $\mathrm{Cl} 4$ & $\begin{array}{l}\text { I go all out to spread the message about } \\
\text { destination when I see many posts about it in social } \\
\text { media }\end{array}$ & 0.751 & & \\
\hline & $\mathrm{Cl} 5$ & $\begin{array}{l}\text { I tend to see the popularity of the destination before } \\
\text { I start recommending it to my friends on social } \\
\text { media }\end{array}$ & 0.653 & & \\
\hline \multirow{4}{*}{$\begin{array}{l}\text { Online reviews } \\
\text { (Cronbach's } \propto= \\
0.789) \quad \text { (Bronner } \\
\& \text { deHoog }, 2011)\end{array}$} & OR1 & $\begin{array}{l}\text { I read all the posts on a destination in social media } \\
\text { and in turn feel it right to tell my friends / family } \\
\text { about it. }\end{array}$ & 0.641 & 0.786 & 0.48 \\
\hline & OR2 & $\begin{array}{l}\text { I feel telling about the destination will help others } \\
\text { choose the same destination. }\end{array}$ & 0.659 & & \\
\hline & OR3 & $\begin{array}{l}\text { I don't share information on destination when the } \\
\text { number of reviews is too low. }\end{array}$ & 0.717 & & \\
\hline & OR4 & $\begin{array}{l}\text { I don't take a travel decision without seeing the } \\
\text { reviews by my friends and family }\end{array}$ & 0.75 & & \\
\hline \multirow{3}{*}{$\begin{array}{l}\text { Destination image } \\
\text { Satisfaction } \\
\text { (Cronbach's } \propto= \\
0.792 \text { ) } \\
\text { (Castro et al., 2007) }\end{array}$} & DS1 & $\begin{array}{l}\text { I feel I need to go to fulfil the desire to visit the } \\
\text { destination when a lot is said about it in SM }\end{array}$ & 0.804 & 0.777 & 0.543 \\
\hline & DS2 & $\begin{array}{l}\text { I think it is of utmost importance to visit the place } \\
\text { when a lot of good posts are written about it }\end{array}$ & 0.587 & & \\
\hline & DS3 & $\begin{array}{l}\text { I am sure I would be happy when I visit the place } \\
\text { after I read all posts }\end{array}$ & 0.799 & & \\
\hline \multirow{3}{*}{$\begin{array}{l}\text { Destination Image } \\
\text { Trust (Cronbach's } \\
\propto=0.884) \\
\text { (Chen \&Tsai, 2007) }\end{array}$} & DT1 & $\begin{array}{l}\text { I tend to develop a faith in destination when a lot is } \\
\text { written about it }\end{array}$ & 0.659 & 0.715 & 0.45 \\
\hline & DT2 & $\begin{array}{l}\text { I am sure that my visit will be enjoyable when I visit } \\
\text { the destination widely talked about }\end{array}$ & 0.581 & & \\
\hline & DT3 & $\begin{array}{l}\text { I agree that more the posts about the destination } \\
\text { helps in positively evaluation }\end{array}$ & 0.776 & & \\
\hline \multirow{3}{*}{$\begin{array}{l}\text { eWOM } \\
\text { (Cronbach's } \\
\propto=0.812) \quad(\text { Jeong } \\
\text { \& Jang, 2011) }\end{array}$} & EWM1 & $\begin{array}{l}\text { My friends on social media network often ask my } \\
\text { advice about new destinations }\end{array}$ & 0.771 & 0.865 & 0.68 \\
\hline & EWM2 & $\begin{array}{l}\text { I spend a lot of time talking with my friends on } \\
\text { social media about places to visit }\end{array}$ & 0.878 & & \\
\hline & EWM3 & $\begin{array}{l}\text { My friends usually give me good advice on where } \\
\text { to go during vacations }\end{array}$ & 0.826 & & \\
\hline
\end{tabular}




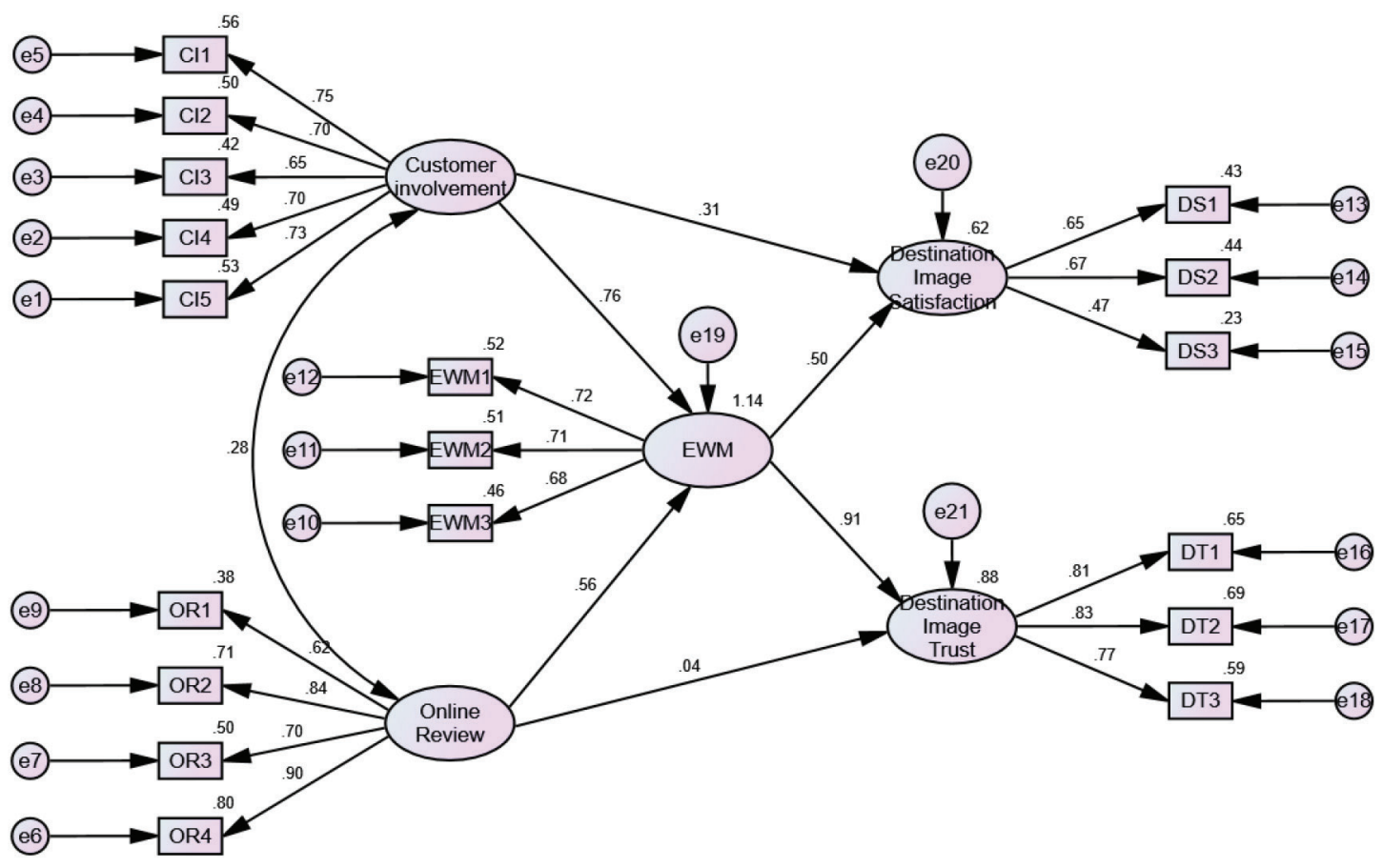

Figure 2: Standardized Structural Equation Model

Table 3: Standardised regression weights of the model (level of significance 0.01)

\begin{tabular}{|l|c|l|c|c|c|c|}
\hline Dependent variable & & \multicolumn{1}{|c|}{ Independent variable } & Estimate & S.E. & C.R. & P \\
\hline eWOM & $\leftarrow$ & Customer involvement & 0.653 & 0.043 & 15.064 & ${ }^{* * *}$ \\
\hline eWOM & $\leftarrow$ & Online Review & 0.426 & 0.028 & 15.167 & ${ }^{* * *}$ \\
\hline Destination Image Satisfaction & $\leftarrow$ & eWOM & 0.523 & 0.085 & 6.131 & ${ }^{* * *}$ \\
\hline Destination Image Trust & $\leftarrow$ & eWOM & 1.264 & 0.09 & 14.063 & ${ }^{* * *}$ \\
\hline Destination Image Satisfaction & $\leftarrow$ & Customer involvement & 0.277 & 0.073 & 3.817 & ${ }^{* * *}$ \\
\hline Destination Image Trust & $\leftarrow$ & Online Review & 0.043 & 0.054 & 0.799 & 0.424 \\
\hline
\end{tabular}

Table 4: Decomposition of direct, indirect and total effects of standardised model

\begin{tabular}{|l|l|c|c|c|}
\hline Predictor Variable & \multicolumn{1}{|c|}{ Dependent Variable } & Direct Effects & Indirect Effects & Total Effects \\
\hline \multirow{3}{*}{ eWOM } & Involvement & $0.426(0.01)$ & - & $0.426(0.01)$ \\
\cline { 2 - 5 } & Online reviews & $0.653(0.01)$ & - & $0.653(0.01)$ \\
\hline \multirow{3}{*}{ Destination Image Trust } & Involvement & - & $0.826(0.01)$ & $0.826(0.01)$ \\
\cline { 2 - 5 } & Online reviews & $0.043(0.609)$ & $0.538(0.01)$ & $0.581(0.01)$ \\
\cline { 2 - 5 } & eWOM & $1.264(0.01)$ & - & $1.264(0.01)$ \\
\hline \multirow{2}{*}{ Destination Image Satisfaction } & Involvement & $0.227(0.01)$ & $0.342(0.01)$ & $0.619(0.01)$ \\
\cline { 2 - 5 } & Online reviews & - & $0.223(0.01)$ & $0.223(0.01)$ \\
\hline
\end{tabular}


The above table illustrates the regression weights existing between the dependent and independent variables. All the independent variables exhibit significance except online review with respect to destination image trust. Table 4 gives us the direct, indirect and total effects existing in between the variables of the proposed model. In this case we consider the t-statistic and the level of significance between the predictor variables eWOM, destination image trust and destination image satisfaction and the dependent variables eWOM, involvement and online reviews. The direct and indirect effects help to identify the mediating effects of eWOM with respect to destination image trust and destination image satisfaction.

\section{References}

Ajzen, I. (1991). The theory of planned behavior. Organizational Behavior and Human Decision Process, 50(2), 179-211.

Anderson, E. (1998). Customer Satisfaction and Word-of-Mouth. Journal of Service Research, 1(1), 5-17.

Anderson, J. C., \& Gerbing, D. W. (1988). Structural Equation Modeling in Practice: A Review and Recommended Two-step Approach. Psyhological Bulletin, 103(3), 411-423.

Assaker, G., Vinzi, V., \& O'Connor, P. (2011). Examining the effect of novelty seeking, satisfaction, and destination image on tourists' return pattern: A two factor, non-linear latent growth model. Tourism management, 32(4), 890-901. doi:10.1016 j.tourman.2010.08.004.

Baloglu, S., \& McCleary, K. (1999). A Model of Destination Image Formation. Annals of Tourism Research, 26(4), 868-897. https:// doi.org/10.1016/S0160-7383(99)00030-4.

Beerli, A., \& Martín, J. (2004). Factors influencing destination image. Annals of Tourism Research, 31(3), 657-681. doi:10.1016/j. annals.2004.01.010.

Beerli, A., Meneses, G. D., \& Gil, S. M. (2007). Self-congruity and destination choice. Annals of Tourism Research, 34(3), 571-587. doi:10.1016/j.annals.2007.01.005.

Bentler, P. M. (1990). Comparative fit indices in Structural models. Psychological Bulletin, 107(2), 238-246.

Bernkopf, D., \& Nixon, L. (2019). The Impact of Visual Social Media on the Projected Image of a Destination: The Case of Mexico City on Instagram. Information and Communication Technologies in Tourism, 145-157. doi:10.1007/978-3-030-05940-8_12 .

Berthon, P., Pitt, L., Plangger, K., \& Shapiro, D. (2012). Marketing meets Web 2.0 , social media, and creative consumers :Implications for international marketing strategy. Business Horizons, 55(5), 261-271.

Bickart, B., \& Schindler, R. (2001). Internet forums as influential sources of consumer information. Journal of Interactive Marketing, 15(3), 31-40.

Bokunewicz, J., \& Shulman, J. (2017). Influencer identification in Twitter networks of destination marketing organizations. Journal of Hospitality and Tourism Technology, 8(2), 205-219.
Bowen, J., \& Baloglu, S. (2015). Common themes across social media research. Worldwide Hospitality and Tourism Themes, 7(3), 314-319. https://doi.org/10.1108/WHATT-04-2015-0022.

Boyd, D., \& Ellison, N. (2008). Social network sites : Definiition , history, and scholarship. Journal of Computer-Mediated Communication, 13(1), 210-230.

Bronner, F., \& de Hoog, R. (2011). Vacationers and eWOM: who posts, and why, where, and what? Journal of Travel Research, 50(1), 15-26. doi: 10.1177/0047287509355324.

Brown, J., \& Reingen, P. (1987). Social Ties and Word-of-Mouth Referral Behavior. Journal of Consumer Research, 14, 350-363.

Buhalis, D. (1998). Strategic Use of Information Technologies in the Tourism Industry. Tourism Management, 19(5), 409-421. https://doi.org/10.1016/S0261-5177(98)00038-7.

Buhalis, D., \& Licata, C. (2002). The future of e-tourism intermediaries . Toursim Management, 23(3), 207-220.

Buhalis, D., \& Zoge, M. (2007). The strategic impact of the Internet on the tourism industry. Information and Communication Technologies in Tourism , 2007(2007), 481-492.

Cai, L., Feng, R., \& Breiter, D. (2003). Tourist purchase decision involvement and information preferences. Journal of Vacation Marketing, 10(2), 138-148.

Campbell, D. T., \& Fiske, D. W. (1959). Convergent and discriminant validation by the multitrait-multimethod matrix. Psychological Bulletin, 56, 81-105.

Castro, C. B., Armario, E. M., \& Ruiz, D. M. (2007). The influence of market heterogeneity on the relationship between a destination's image and tourists' future behaviour. Tourism Management, 28(1), 175- 187. https://doi.org/10.1016/j.tourman.2005.11.013.

Chen, C., \& Phou, S. (2013). A closer look at destination: Image, personality, relationship and loyalty. Tourism Management, 36(2013), 269-278. https://doi.org/10.1016/j. tourman.2012.11.015.

Chen, C., \& Tsai, D. (2007). How destination image and evaluative factors affect behaioural intentions ? Tourism Management, 28, 1115-1122.

Chen, C.-F., \& Phou, S. (2013). A closer look at destination: Image, personality, relationship and loyalty . Tourism Management, 36(6), 269-278. https://doi.org/10.1016/j.tourman.2012.11.015.

Chi, C., \& Qu, H. (2008). Examining the structural relationships of destination image, tourist satisfaction and destination loyalty: An integrated approach. Tourism Management, 29(4), 624-636. https://doi.org/10.1016/j.tourman.2007.06.007.

Clements, C. J., \& Josiam, B. M. (1995). Role of involvement in the travel decision. Journal of Vacation Marketing, 1(4), 337-348.

del Bosque, I. R., \& San Martin, H. (2008). Tourist Satisfaction: A cognitive-affectve model. Annals of Tourism Research, 35(2), 551-573. doi:10.1016/j.annals.2008.02.006.

Dellarocas, C. (2003). The Digitization of Word of Mouth: Promise and Challenges of Online Feedback Mechanisms. Management Science, 49(10), 1275-1444. https://doi.org/10.1287/mnsc.49. 10.1407.17308. 
Di Pietro, L., Di Virgilio, F., \& Pantano, E. (2012). Social network for the choice of tourist destination: attitude and behavioural intention. Journal of Hospitality and Tourism, 3(1), 60-76. DOI 10.1108/17579881211206543.

Do, S.-J., \& Hwang, J.-S. (2009). Rapid Communication:How Consumers Evaluate eWOM (Electronic Word-of-Mouth) Messages. Cyber Psychology \& Behaviour, 12(2), 193-201.

Engel, J., Blackwell, R., \& Miniard, P. (1993). Consumer behaviour (8th ed.). Fort Worth: Dryden Press.

Erkan, I., \& Evans, C. (2016). The influence of eWOM in social media on consumers' purchase intentions: An extended approach to information adoption. Computers in Human Behavior, 61, 47-55.

Fornell, C., \& Larcker, D. F. (1981). Evaluating Structural Equation Models with Unobservable Variables and Measurement Error. Journal of Marketing Research, 18(1), 39-50.

Fotis, J. N., Buhalis, D., \& Rossides, N. (2012). Social media use and impact during the holiday travel planning process. In: M. Fuchs, F. Ricci, \& L. Cantoni, Information and Communication Technologies in Tourism (pp. 13-24). Vienna , Austria: SpringerVerlag.

Fotis, J., Buhalis, D., \& Rossides, N. (2011). Social Media Impact on Holiday Travel Planning: The Case of the Russian and the FSU Markets. International Journal of Online Marketing, 1(4), 1-19.

Giao, H., Ngan, N., Phuc, N., Tuan, H., Hong, H., Anh, H., et al. (2020). How Destination Image Factors Affect Domestic Tourists Revisit Intention to Ba Ria-Vung Tau Province, Vietnam. Journal of Asian Finance, Economics and Business, 7(6), 209-220. doi:10.13106/jafeb.2020.vol7.no6.209.

Goodrich, K., \& de Mooij, M. (2014). How 'social' are social media? A cross-cultural comparison of online and offline purchase decision influences. Journal of Marketing Communications, 20(1-2), 103-116. https://doi.org/10.1080/13527266.2013.797 773.

Gunawan, D., \& Huarng, K. (2015). Viral effects of social network and media on consumers' purchase intentions. Journal fo Business Research, 68(2015), 2237-2241. https//doi. org/10.1016/j.jbusres.2015.06.004.

Gursoy, D., \& McCleary, K. (2004). An integrative model of tourists' information search behaviour. Annals of Tourism Research, 31(2), 353-373. https://doi.org/10.1016/j.annals.2003.12.004.

Habibi, M., Laroche, M., \& Richard, M. (2014). The roles of brand community and community engagement in building brand trust on social media. Computers in Human Behaviour, 37, 152-161. http://dx.doi.org/10.1016/j.chb.2014.04.016.

Hadddouche, H., \& Salomone, C. (2018). Generation Z and the tourist experience: tourist stories and use of social networks. Journal of Tourism Futures, 4, 69-79. https://doi.org/10.1108/ JTF-12-2017-0059.

Hair, J., Anderson, R., Tatham, R., \& Black, W. (1998). Multivariate Data Analysis (5th ed.). Upper Saddle River, NJ: Prentice-Hall.
Hays, S., Page, S. J., \& Buhalis, D. (2013). Social media as a destination marketing tool: its use by national tourism organisations. Current Issues in Tourism, 211-237.

Hennig-Thurau, T., Gwinner, K., Walsh, G., \& Gremler, D. (2004). Electronic word-of-mouth via consumer-opinion platforms : what motivates consumers to articulate themselves on the internet? Journal of Interactive Marketing, 18(1), 38-52. DOI: 10.1002/dir.10073.

Hu, L., \& Bentler, P. M. (1999). Cutoff criteria for fit indexes in covariance structure analysis: Conventional criteria versus new alternatives. Structural Equation Modelling: A Multidisciplinary Journal , 6(1), 1-55.

Huyen, H., \& Binh, T. (2020). Impact of Destination Image and Satisfaction on Tourist Loyalty:Mountain Destinations in Thanh Hoa Province, Vietnam. Journal of Asian Finance, Economics and Business, 7(4), 185-195. doi:10.13106/jafeb.2020.vol7. no4.185.

Ip, C., Leung, R., \& Law, R. (2011). Progress and development of information and communication technologies in hospitality. International Journal of Contemporary Hospitality Management, 533-551. http://dx.doi. org/10.1108/09596111111130029.

Jalilvand, M., \& Heidari, A. (2017). Comparing face-to-face and electronic word-of-mouth in destination image: The case of Iran. Information Technology and People, 30(4), 710-735. https://doi.org/10.1108/ITP-09-2016-0204.

Jalilvand, M., \& Samiei, N. (2012). The impact of electronic word on tourism destination choice. Internet Research, 22(5), 591612. https:// doi 10.1108/10662241211271563.

Jeong, E., \& Jang, S. (2011). Restaurant experiences triggering positive electronic word-of-mouth (eWOM) motivations. International Journal of Hospitality Management, 30(2), 356366. https://doi.org/10.1016/j.ijhm.2010.08.005.

Johra, K., \& Mohammed, A. (2013). Roles of customer involvement in rapport and satisfaction. Asia Pacific Journal of Marketing and Logistics, 25(3), 452-471.

Kaplan, A. M. (2012). If you love something, let it go mobile: mobile marketing and mobile social. Business Horizons, 129139.

Kaplan, A., \& Haenlein, M. (2010). Users of the world, unite! The challenges and opportunities of Social Media. Business Horizons, 4(1), 59-68. doi:10.1016/j.bushor.2009.09.003.

Kavoura, A., \& Stavrianeas, A. (2015). The importance of social media on holiday visitors' choices - the case of Athens, Greece. EuroMed Journal of Business, 10(3), 360-374. https://doi. org/10.1108/EMJB-03-2015-0016.

Kiralova, A., \& Pavliceka, A. (2015). Development of Social Media Strategies in Tourism Destination . Procedia - Social and Behavioral Sciences 175(2015), 358-366.

Konecnik, M., \& Gartner, W. C. (2007). Customer-based brand equity for a destination. Annals of Tourism Research, 34(2), 400-421. doi:10.1016/j.annals.2006.10.005. 
Lang-Faria, W., \& Elliot, S. (2012). Understanding the role of social media in destination marketing. Tourismos, 7(1), 193-211.

Lee, J., Park, D., \& Han, I. (2008). The effect of negative online consumer reviews on product attitude: An information processing view. Electronic Commerce Research and Applications, 7(3), 341-352. https://doi.org/10.1016/j. elerap.2007.05.004.

Lehto, X., Kim, D., \& Morrison, A. (2005). The effect of prior destination experience on online information search behaviour. Tourism and Hospitality Research, 6(2), 160-178. https://doi. org/10.1057\%2Fpalgrave.thr.6040053.

Lim, Y., Chung, Y., \& Weaver, P. (2012). The impact of social media on destination branding: Consumer-generated videos versus destination marketer-generated videos. Journal of Vacation Marketing, 18(3), 197-206. https://doi. org/10.11772F1356766712449366.

Litvin, S., Goldsimth, R., \& Pan, B. (2008). Electronic wordof-mouth in hospitality and tourism management. Tourism Management, 29(3), 458-468. https://doi.org/10.1016/j. tourman.2007.05.011.

Mangold, W., \& Faulds, D. (2009). Social media : The new hybrid element of promotion mix. Business Horizons, 52(4), 357-365.

McCartney, G., Butler, R., \& Bennett, M. (2008). A strategic use of the communication mix in the destination image-formation process. Journal of Travel Research, 47(2), 183-196. https:// doi.org/10.11772F0047287508321201.

Murphy, L., Benckendorff, P., \& Moscardo, G. (2007). Linking Travel Motivation, Tourist Self-Image and Destination Brand Personality. Journal of Travel \& Tourism Marketing, 22(2), 4559. doi:10.1300/J073v22n02_04.

Nguyen, X. (2020). Factors That Influence the Intentions to Revisit Korea of Vietnamese Tourists. Journal of Asian Finance, Economics and Business, 7(4), 247-258. doi:10.13106/ jafeb.2020.vol7.no4.247.

O'Connor, P. (2010). Managing a Hotel's Image on TripAdvisor. Journal of Hospitality Marketing \& Management, 19, 754-772. DOI: 10.1080/19368623.2010.508007.

Oz, M. (2015). Social media utilization of tourists for travel-related purposes. International Journal of Contemporary Hospitality Management, 27(5), 1003-1023. http://dx.doi.org/10.1108/ IJCHM-01-2014-0034.

Park, D., \& Lee, J. (2008). eWOM overload and its effect on consumer behavioral intention depending on consumer involvement. Electronic Commerce Research and Applications, 7(1), 386-398. doi:10.1016/j.elerap.2007.11.004.

Parra-López, E., Bulchand-Gidumal, J., Gutiérrez-Taño, D., \& DíazArmas, R. (2011). Intentions to use social media in organizing and taking vacation trips. Computers in Human Behaviour, 27(2), 640-654. https://doi.org/10.1016/j.chb.2010.05.022.

Pino, G., Peluso, A., Del Vecchio, P., Ndou, V., Passiante, G., \& Guido, G. (2018). A methodological framework to assess social media strategies of event and destination management organizations. Journal of Hospitality, Marketing \&
Management, 28(2), 189-216. https://doi.org/10.1080/193686 23.2018.1516590.

Prayag, G., \& Ryan, C. (2012). Antecedents of Tourists' Loyalty to Mauritius The Role and Influence of Destination Image, Place Attachment, Personal Involvement, and Satisfaction. Journal of Travel Research, 51(3), 342-356.

Puri, A. (2007). The Web of Insights: The Art and Practice of Webnography. International Journal of Marketing Research, 49(3), 387-408. https://doi.org/10.1177\% 2F147078530704900308.

Rageh, A., Melewar, T., \& Woodside, A. (2013). Using netnography research method to reveal the underlying dimensions of the customer/tourist experience. Qualitative Market Research, 16(2), 126-149. https://doi.org/10.1108/13522751311317558.

Ribbink, D., van Riel, A., Liljander, V., \& Streukens, V. (2004). Comfort your online customer: quality, trust and loyalty on the internet. Managing Service Quality, 14(6), 446-456. http:// dx.doi.org/10.1108/09604520410569784.

Rodriguez-Molina, M. A., Frias-Jamilena, D. M., \& CastanedaGarcia, J. A. (2015). The contribution of website design to the generation of tourist destination image: The moderating effect of involvement. Tourism Management, 47, 303-317. https://doi. org/10.1016/j.tourman.2014.10.001.

Ruiz-Molina, M., Gil-Saura, I., \& Seic, M. (2013). The use of ICT in established and emerging tourist destinations: a comparitive analysis of hotels. Journal of Hospitality and Tourism Technology, 4(2), 96-118.

See-To, E., \& Ho, K. (2014). Value co-creation and purchase intention in social network sites:The role of electronic Wordof-Mouth and trust - A theoretical analysis. Computers in Human Behaviour, 31(2), 182-189. http://dx.doi.org/10.1016 j.chb.2013.10.013.

Sevin, E. (2013). Places going viral: Twitter usage patterns in destination marketing and place branding. Journal of Place Management and Development, 6(3), 227-239.

Shen, H., Song, C., Li, M., \& Jiang, Q. (2015). Shaping Destination Images through Social Networking Sites: A Case Study of Singapore. Advances in Hospitality and Leisure, 11, 89-107. https://doi.org/10.1108/S1745-354220150000011006.

Shim, S., Eastlick, M., Lotz, S., \& Warrington, P. (2001). An online prepurchase intentions model: The role of intention to search. Journal of Retailing, 77(3), 397-416. https:/doi.org/10.1016/ S0022-4359(01)00051-3.

Sigala, M. (2012). The Integration and Impact of Web 2.0 on Business Operations and Strategies. In: M. Sigala, E. Christou, \& U. Gretzel, Social media in Travel, Tourism and Hospitality (pp. 7-10). Surrey, UK: Ashgate Publishing Limited.

Sotiriadis, M., \& van Zyl, C. (2013). Electronic word-of-mouth and online reviews in tourism services: the use of twitter by tourists. Electronic Commerce Research, 13(2013), 103-124. https:// doi.org/10.1007/s10660-013-9108-1.

Stojanovic, I., Andreu, L., \& Curras-Perez, R. (2018). Effects of the intensity of use of social media on brand equity: An 
empirical study in a tourist destination. European Journal of Management and Business Economics, 27(1), 83-100. https:// doi.org/10.1108/EJMBE-11-2017-0049.

UNWTO. (2019). International Tourism Highlights. Madrid: World Tourism Organisation .

Yan, Q., Wu, S., Wang, L., Wu, P., Chen, H., \& Wei, G. (2016). E-WOM frome-commerce websites and social media: Which will consumers adopt? Electronic Commerce Research and Applications, 17(5), 62-73. http://dx.doi.org/10.1016/j.elerap.2016.03.004.
Ye, Q., Law, R., Gu, B., \& Chen, W. (2011). The influence of user-generated content on traveler behavior: An empirical investigation on the effects of e-word-of-mouth to hotel online bookings. Computers in Human Behaviour, 27(2), 634-639. doi:10.1016/j.chb.2010.04.014.

Zins, A., \& Lin, S. (2016). From intended to projected destination image elements: the case of prefectures in China. International Journal of Culture, Tourism and Hospitality Research, 10(1), 38-52. https://doi.org/10.1108/IJCTHR-05-2015-0033. 